\title{
GENETIC DIVERGENCE IN SELECTED DURUM WHEAT GENOTYPES OF ETHIOPIAN PLASM
}

\author{
AREGA GASHAW, HUSSEIN MOHAMMED ${ }^{1}$ and HARJIT SINGH ${ }^{2}$ \\ Sirinka Agricultural Research Center, Woldia, Ethiopia \\ ${ }^{1}$ Debub University, College of Agriculture, Awassa, Ethiopia \\ ${ }^{2}$ Alemaya University, College of Agriculture, Harar, Ethiopia
}

(Received 29 January, 2007; accepted 29 May, 2007)

\begin{abstract}
Wheat of both the tetraploid (Triticum durum Desf.) and hexaploid (Triticum aestivum L.), is the most important cereal crop in Ethiopia, ranking third in total production (17\%) next to maize (Zea mays L.) and tef (CSA, 2002). Wheat covers a total arable land of 110,434 ha with average productivity of about $8.4 \mathrm{qt} \mathrm{ha}^{-1}$, which is below the national average (14.4 qt ha-1). A field experiment was conducted at the Sirinka Agricultural Research Centre, northeastern Ethiopia, to estimate the genetic divergence among indigenous durum wheat (Triticum durum Desf.) genotypes of diverse origin, and clustering them into homogenous groups for the hybridisation programme. Genetic divergence analysis was done based on multivariate analysis using Mahalanobis's $\mathrm{D}^{2}$ statistic, which grouped the durum wheat genotypes into ten clusters. The highest inter-cluster distance was between clusterll and cluster-lll $\left(\mathrm{D}^{2}=57.15\right)$. There was no correspondence between geographic and genetic distances, i.e., germplasms, collected from the same geographic area were placed into different cluster groups and those collected from different geographic regions were placed into the same cluster. The presence of significant genetic variability among the evaluated durum wheat genotypes suggests an opportunity for improvement of grain yield through hybridisation of genotypes from different clusters and subsequent selection from the segregating generations.
\end{abstract}

Key Words: Clustering, Ethiopia, hybridisation, Triticum

\section{RÉSUMÉ}

Le Blé, à la fois du type tetra- (Triticum durum Desf.) et hexaploïde (Triticum aestivum L.) constitue la culture céréalière la plus importante en Ethiopie; classée $3^{e}$ par sa production totale (17\%) après le maïs (Zea Mays L.) et le tef (CSA, 2002). Le blé couvre une totalité de terres arable de 110.434 ha avec une productivité d'environ $8,4 \mathrm{qt} \mathrm{ha}^{-1}$, qui se trouve en-dessous de la moyenne nationale $\left(14,4 \mathrm{qt} \mathrm{ha}^{-1}\right)$. Une expérience de terrain a été menée au Centre de Recherche Agricole de Sirinka dans le nord-est éthiopien en vue de pouvoir estimer les divergences génétiques au sein de génotypes de diverses origines, blé durum indigène (Tricicum durum Desf.) et en vue de pouvoir les conglomérer ensemble en groups homogènes pour le programme d'hybridation. L'analyse de la divergence génétique était faite en se basant sur l'analyse multi variable, utilisant les statistiques $\mathrm{D}^{2}$ de Mahalanobis, qui a groupé les génotypes de blé durum en 10 groupes. La plus grande distance inter-groupe était notée entre le conglomérat II et III $\left(D^{2}=57,15\right)$. Il $n$ 'y avait pas de correspondance entre distance géographiques et distance génétiques $\mathrm{c}^{1}$-à-d, que les germoplasmes collectionnés à partir de mêmes zones géographiques étaient placés dans différents groupes et ceux collectés à partir de régions géographiques différents étaient placés dans le même conglomérat. La présence d’une variabilité génétique significative au sein des génotypes de blé durum évalués suggère une opportunité pour l'amélioration du rendement de grain, à travers l'hybridation de génotypes des différents conglomérats et sélection subséquente à partir de générations à ségrégation.

Mots Clés: Conglomération, Ethiopie, hybridation, Triticum 


\section{INTRODUCTION}

Wheat of both the tetraploid (Triticum durum Desf.) and hexaploid (Triticum aestivum L.), is the most important cereal crop in Ethiopia, ranking third in total production (17\%) next to maize (Zea mays L.) and tef (CSA, 2002). Wheat covers a total arable land of 110,434 ha with an average productivity of about $8.4 \mathrm{qt} \mathrm{ha}^{-1}$, which is below the national average (14.4 qt ha-1).

Most of the tetraploid wheat varieties, grown in Ethiopia are landraces consisting of a large number of different genetic lines. Purseglove (1975) reported the presence of genetic diversity of durum wheat in Ethiopia and Zohary (1970) identified Ethiopia as the centre of origin for tetraploid wheat. However, the absence of ancestral forms and wild relatives ruled-out Ethiopia as the centre of origin of cultivated wheat (Pecetti et al., 1992).

The major breeding objective in durum wheat is to create new improved genotypes with features that contribute to greater yield potential, increased yield stability and improved product quality (Poehlman and Sleper, 1995). To make the crossing programme effective, parents should belong to different genetic clusters. The more distant the parents within overall limits of fitness are the greater the chances of obtaining higher amount of heterotic expression in F1's and broad spectrum of variability in segregating populations (Reddy, 1988). However, crossing of genotypes belonging to the same genetic cluster would not be expected to yield desirable recombinants.

The use of D2 statistic (Mahalanobis, 1936) is one of the most important biometrical techniques for estimating genetic divergence present in a population. Selection of parents based on the extent of genetic divergence has been successfully utilised in different crop species (Singh and Gupta, 1979; Jain et al., 1981; Ghaderi et al., 1984; Jatasra and Paroda, 1978; Shoran and Tandom, 1995).

This experiment was aimed at identifying genetically divergent durum wheat parents with desirable traits for hybridisation particularly for moisture stressed areas.
The experiment was conducted at Geregara and Kone testing sites of Sirinka Agricultural Research Centre, northeastern Ethiopia. The trial was evaluated for two cropping seasons at Geregera located at an altitude of 2650 masl; and for one cropping season at Kone located at 2800 masl. Rainfall in both locations is erratic in distribution and less predictable with uni-modal pattern having a mean annual rainfall of 1105 and 1054 millimeter, respectively.

The experiment consisted of 64 durum wheat genotypes of which 20 are exotic (received from CIMMYT) and the remaining 44 were randomly taken from the indigenous germplasm collections. The indigenous durum wheat germplasm was collected from the central highlands and western part of the country, where durum wheat is widely cultivated.

The trial was laid-down using $8 \times 8$ triple lattice design. Each genotype was planted in four rows of $2.5 \mathrm{~m}$ by $0.2 \mathrm{~m}$. Seed rate was adjusted based on the kernel size where seed rates of 125 and $150 \mathrm{~kg} \mathrm{ha}^{-1}$ were used for small kernelled and large kernelled genotypes, respectively (Tanner et al., 1991). Urea and diammonium phosphate (DAP) fertilisers were applied at the rate of 50 and $100 \mathrm{~kg} \mathrm{ha}^{-1}$, respectively. The whole of the DAP was applied at sowing, while urea was applied in splits with the first half applied at sowing and the second top-dressed at full tillering stage. The trial was hand-weeded at 20 and 45 days after emergence.

Data on plant height, number of spikeletes spike $^{-1}$, number of kernels spike ${ }^{-1}$ and number of tillers plant ${ }^{-1}$ were recorded from five randomly taken plants from the central two rows, which were tagged ahead of heading. Data for the rest of the characters were recorded from the whole plots.

The data were subjected to Analysis of Variance (ANOVA) using MSTAT-C computer software (Michigan State University, 1988). Genetic divergence analysis was computed based on multivariate analysis using Mahalanobis's D ${ }^{2}$ statistic (Mahalanbis, 1936) using Statistical 
Package for Agricultural Research (SPAR-1) software developed by IASRA, New Delhi.

Squared distances $\left(D^{2}\right)$ for each pair of genotype combinations were computed using the following formula:

$D^{2}{ }_{i j}=\left(X_{i}-X_{j}\right) S^{-1}\left(X_{i}-X_{j}\right)$,

where:

$\mathrm{D}^{2}{ }_{\mathrm{ij}}=$ the square distance between any two genotypes $\mathrm{i}$ and $\mathrm{j}$,

$\mathrm{X}_{\mathrm{i}}$ and $\mathrm{X}_{\mathrm{j}}=$ the vectors for the values for $\mathrm{i}^{\text {th }}$ and $\mathrm{j}^{\text {th }}$ genotypes, and

$\mathrm{S}^{-1}=$ the inverse of pooled variance covariance matrix

Clustering of genotypes was done based on the squared distance $\left(\mathrm{D}^{2}\right)$ values using Tocher's method as described by Singh and Chaudhary (1985). Average intra- and inter-cluster $\mathrm{D}^{2}$ values were estimated using the formula:

$\sum \frac{D_{1}^{2}}{n}$, where $\sum D_{i}^{2}$

is the sum of distances between all possible combinations (n) of durum wheat genotypes included in a cluster. Significance of the squared distances for each cluster was tested against the tabulated $X^{2}$ values at $\mathrm{P}$ degree of freedom at $5 \%$ probability level, where $P$ represents the number of characters used for clustering genotypes.

\section{RESULTS AND DISCUSSION}

There were highly significant $(\mathrm{P}<0.02)$ genotypic differences for all characters considered, revealing the existence of substantial amount of variation among the genotypes. Likewise, Wilk's test of aggregate variation showed significant differences among genotypes, when all the characters were pooled except for the grain filling period. This justified the need to estimate squared distance values for the genotype combinations using these characters.

Based on $\mathrm{D}^{2}$ value estimates of genetic divergence, the 64 durum wheat genotypes were grouped into ten distinct clusters (Table 1). Cluster-1 and cluster-VII consisted of a maximum of nine genotypes each. This was followed by cluster-VI, cluster-VIII and cluster-X with eight genotypes each. Cluster-III and IX had the least number of genotypes (three each).

Within the indigenous germplasms, there was no correspondence between geographic and genetic distances. This suggested that germplasm collected from the same geographic area were not necessarily closely related and different regions did not necessarily have different genetic background. Such occurrences could be due to the same genetic background (base population) of the germplasm, being spread in the country. This suggests that germplasm from the same region might have the same genetic background and those collected from the same region might have different genetic background. Similar findings appeared in earlier reports (Garg and Gautam, 1988; Walia and Garg, 1996; Singh

TABLE 1. Summary of cluster group for 64-durum wheat germplasm

\begin{tabular}{lll}
\hline Cluster group & Total number of germplasm & Origin \\
\hline 1 & 9 & All of them are exotic \\
II & 5 & All of them are indigenous \\
III & 3 & All of them are exotic \\
IV & 4 & All of them are indigenous \\
V & 7 & All of them are indigenous \\
VI & 8 & All of them are indigenous except one exotic genotype \\
VII & 9 & All of them are indigenous \\
VIII & 8 & All of them are indigenous \\
IX & 3 & All of them are indigenous \\
X & 8 & All of them are exotic except one indigenous genotype \\
\hline
\end{tabular}


et al., 2003). Most reports attributed this to lack of parallelism between genetic and geographic diversity due to movement of germplasm.

The exotic and indigenous germplasm were grouped into different clusters. The only exceptions were cluster-VI and cluster-X, where the former consisted of one exotic and seven indigenous genotypes, while cluster- $\mathrm{X}$ consisted of one indigenous and seven exotic genotypes. This clearly showed that wider geographic distances for indigenous and exotic germplasm created wider genetic variability because of adaptation to different environmental conditions. The present finding is in agreement with Adary (1978) who reported relationships between genetic divergence and geographical distance among countries of origin and to environmental differences among sites of collection.

Overall, cluster-III (Table 2) possessed desirable combinations of characters; namely, high number of kernels plant ${ }^{-1}$ (47.83), high grain yield (4343 kg ha-1), high harvest index (43.5\%), high biological yield $\left(10 \mathrm{t} \mathrm{ha}^{-1}\right)$ and high thousandkernel weight (39.2 g). This cluster could serve as valuable parent for future crossing programme. Similarly, cluster-IX comprised genotypes having important traits and could also be used as parents to develop superior cultivars for dry-land areas, where terminal moisture-stress is a major problem.

Plant height accounted the highest contribution to total genetic divergence (14.0\%) followed by grain yield (10.3\%) and number of kernels spike ${ }^{-1}(10.2 \%)$, while days to maturity had the least contribution (5.7\%) (Table 1). Similar findings were reported by Das and Brothakur (1973) for days to heading, thousand seeds weight and plant height contribution to genetic divergence in rice.

\section{Estimates of intra- and inter-cluster squared}

distance $\left(\mathbf{D}^{2}\right)$. Intra-and inter-cluster $\mathrm{D}^{2}$ values among the ten clusters are presented in Table 3. The magnitude of intra-cluster distances indicates the extent of genetic diversity among genotypes of the same cluster. The intra-cluster distance varied from 1.66 to 5.06, with the maximum distance in cluster-VII and the minimum in cluster-IX suggests close relationships of individual genotypes.

The highest inter-cluster distance was exhibited between clusters II and III $\left(\mathrm{D}^{2}=42.90\right)$, indicating wider genetic divergence among the clusters. The lowest $\mathrm{D}^{2}$ value was observed between clusters II and VI $\left(D^{2}=4.20\right)$, indicating

TABLE 2. Values of the eleven quantitative characters of ten clusters of durum wheat germplasms

\begin{tabular}{|c|c|c|c|c|c|c|c|c|c|c|c|}
\hline \multirow[t]{2}{*}{ Character } & \multicolumn{10}{|c|}{ Clusters } & \multirow{2}{*}{$\begin{array}{c}\quad \% \\
\text { Contribution } \\
\text { to divergence }\end{array}$} \\
\hline & I & II & III & IV & V & VI & VII & VIII & IX & $x$ & \\
\hline $\mathrm{DH}$ & 72 & 81 & 76 & 77 & 71 & 76 & 74 & 70 & 71 & 71 & 9.3 \\
\hline DM & 128 & 135 & 133 & 136 & 125 & 130 & 135 & 137 & 127 & 130 & 5.7 \\
\hline $\mathrm{PH}$ & 70.0 & 78.4 & 74.6 & 86.4 & 93.2 & '85.5 & 99.2 & 90.4 & 93.3 & 79.8 & 14.0 \\
\hline NT & 2.4 & 2.9 & 2.6 & 3.1 & 3.0 & 3.0 & 3.0 & 2.0 & 3.2 & 2.6 & 7.5 \\
\hline NSS & 14.7 & 15.33 & 15.39 & 15.8 & 15.04 & 16.18 & 17.18 & 14.84 & 14.51 & 9.6 & \\
\hline NK & 35.6 & 25.5 & 47.83 & 28.8 & 27.07 & 26.65 & 30.53 & 28.28 & 25.6 & 33.5 & 10.3 \\
\hline KYP & 1.37 & 0.87 & 1.9 & 1.17 & 1.03 & 0.97 & 1.29 & 1.08 & 1.13 & 1.54 & 9.7 \\
\hline BY & 8.8 & 7.2 & 10.0 & 7.8 & 9.3 & 7.9 & 10.2 & 9.0 & 8.2 & 9.1 & 8.8 \\
\hline TKW & 37.78 & 36.31 & 39.16 & 40.07 & 38.14 & 34.91 & 42.47 & 38.64 & 40.30 & 45.47 & 8.6 \\
\hline GY & 3615 & 2599 & 4343 & 3005 & 3479 & 2886 & 3698 & 3100 & 3042 & 3663 & 10.3 \\
\hline $\mathrm{HI}$ & 41.2 & 36.3 & 43.5 & 38.6 & 37.4 & 36.4 & 36.5 & 34.5 & 37.4 & 40.3 & 6.3 \\
\hline
\end{tabular}

$\mathrm{DH}$-Days to heading, DM = Days to maturity, $\mathrm{PH}=$ Pklant height, $\mathrm{NT}=$ Number of Tillers per plant, $\mathrm{NSS}=$ Number of spikelets per spike, NK = Number of kernels per spike, $\mathrm{KYP}=$ Kernel yield per plant $(\mathrm{g}), \mathrm{BY}=$ Biological yield $\left(\mathrm{t} \mathrm{ha} \mathrm{C}^{-1}\right), \mathrm{TWK}=$ thousand kernel weight $(\mathrm{g}), \mathrm{GY}=$ Grain yield $\left(\mathrm{kg} \mathrm{ha}^{-1}\right)$ and $\mathrm{HI}=$ harvest index (\%) 
TABLE 3. Intra-cluster (bolded main diagonal) and inter-cluster (off diagonal) $D^{2}$ values among nine clusters of durum wheat germplasm

\begin{tabular}{|c|c|c|c|c|c|c|c|c|c|c|}
\hline Cluster & I & II & III & IV & V & VI & VII & VIII & IX & $x$ \\
\hline I & 3.31 & & & & & & & & & \\
\hline II & $23.62^{\star *}$ & 2.69 & & & & & & & & \\
\hline III & 14.29 & $57.15^{\star \star}$ & 4.88 & & & & & & & \\
\hline IV & $18.75^{\star}$ & 7.08 & $37.58^{\star *}$ & 3.65 & & & & & & \\
\hline V & 12.53 & 19.45 & $35.52^{\star *}$ & 12.39 & 2.72 & & & & & \\
\hline VI & 15.60 & 4.20 & $45.43^{\star \star}$ & 5.48 & 6.86 & 2.10 & & & & \\
\hline VII & $18.75^{\star}$ & 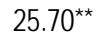 & $26.83^{\star \star}$ & 11.83 & 9.00 & 16.48 & 5.06 & & & \\
\hline VIII & $25.40^{\star \star \star}$ & 11.02 & 42.90 ** & 5.62 & 14.06 & 8.94 & 7.67 & 3.96 & & \\
\hline IX & $20.52^{*}$ & 16.97 & $45.83^{\star *}$ & 7.56 & 4.71 & 6.50 & 14.59 & 14.98 & 1.66 & \\
\hline$X$ & 5.81 & $29.81^{\star *}$ & 15.76 & 17.14 & 12.46 & $20.70^{*}$ & 11.76 & $24.70^{\star \star}$ & 16.48 & 4.71 \\
\hline
\end{tabular}

$x^{2}=18.31$ and 23.21 at $5 \%$ and $1 \%$ probability level, respectively

that these clusters were genetically close. Thus, crossing of genotypes from these two clusters may not produce a high amount of heterotic expression in the $F_{1}$ 's and broad-spectrum of variability in segregating $\left(\mathrm{F}_{2}\right)$ populations. Parents for hybridisation could be selected on the basis of large inter-cluster distance for isolating useful recombinants in the segregating generations. Increasing parental distance implies a greater number of constraining alleles at the desired loci, and then to the extent that these loci recombine in the $\mathrm{F}_{2}$ and $\mathrm{F}_{3}$ generations following a cross of distantly related parents, the greater will be the opportunities for successful selection for any character of yield interest (Ghaderi et al., 1984).

\section{CONCLUSION}

From this study, genotypes in clusters III and IX possess desirable combinations of traits and thus; the genotypes of these two clusters hold great promise as parents to obtain promising heterotic expression in $\mathrm{F}_{1}$ 's and may create considerable variability in the segregating populations.

\section{ACKNOWLEDGEMENTS}

The first author is very grateful to Dr. Wondimu Bayu for his unreserved technical comments during the write up of this paper. The research was funded by Ethiopian Agricultural Research Organization Agricultural Research Training Project (ARTP) and Amhara Agricultural Research Institute (ARARI).

\section{REFERENCES}

Adary, A.H. 1978. Genetic variation in landraces of durum wheat and its value in durum wheat improvement. Ph.D. dissertation, California University.

BFED, The Amhara National Regional State, Bureau of Finance and Economic Development (BFED). 2001. Annual Statistical Bulletin. pp. 29-30.

Bhatt, G.M. 1970. Multivariate analysis approach to selection of parents for hybridization aiming at yield improvement in self-pollinated crops. Autralian. Agric. J. Res. 21:1-7.

Cochran, W.G. and Cox, G.M. 1957. Experimental Designs. John Wiley and Sons, Inc., New York. 611pp.

CSA, 2002. Central Statistics Authority (CSA). 2002. Statistical Abstract. 96pp.

Das, G.R. and Brothakur, D.N. 1973. Genetic divergence in rice. Indian Journal of Genetics 33:436-443.

Garg, D.K. and Gautam, P.L. 1988. Evaluation of local collections of wheat (Triticum spp.) germplasm. Genetica Agraria 42:255-261.

Ghaderi, A., Adams, M.W. and Nassib, A.M. 1984. Relationship between genetic distance and 
heterosis for yield and morphological traits in dry edible bean and faba bean. Crop Science 24:37-24.

Harlan, J.R. 1971. Agricultural Origind: Centers and non-centers. Science 74:468-476.

Jain, K.C., Pandya, B.P. and Pande, K. 1981. Genetic divergence in chickpea. Indian Journal of Genetics 41:220-225.

Jatasra, D.S. and Paroda, R.S. 1978. Genetic divergence in wheat under different environmental conditions. Cereals Res. Commun. 6:307-318.

Mahalanobis, P.C. 1936. The generalized distance in statistics. Pro. India Nat. Inst. Sci. 2:4955.

Michigan State University. 1988. User's Guide to MSTAT-C a software program for the design, management, and analysis of agronomic research experiment, MSU, USA.

Miller, P.A. and Marani, A. 1963. Heterosis and combining ability in diallel crosses of upland cottone (Gossypium hirsutum L.) Crop Scieince 3:441-444.

Norden, A.J. 1980. Breeding methodology in groundnut. In: Gibbons and J.V. Martin (Eds.), pp. 58-61. Proceedings of the international workshop of groundnut, 13-17 October 1980. ICRISAT, Patancheru, India.

Pecetti, L., Damania, A. and Kashour, G. 1922. Geographic variation for spike and grain characteristics in durum wheat germplasm adapted to dry land conditions. Genetic Resources and Crop Evolution 39:97-105.

Poehlam, J.M. and Sleper, D.A. 1995. Breeding Field Crops ( $4^{\text {th }}$ edition). Iowa State University Press. Iowa. pp. 259-261.

Purseglove, J.W. 1975. Tropical Crops; monocotyledons. John Wiley \& Sons, Inc., New York, Pp. 287-291.॥Rao, A.V., A.S.R. Prasad, T.S. Krisha, D.V. Seshu and T.E. Srinivasan. 1981. Genetic divergence among some brown plant hopper resistant rice varieties. Indian Journal of Genetics 41: 179185.
Reddy, P.S. 1988. Genetics, Breeding and Varieties. In: P.S. Reddy (Ed.), pp. 200-317. Groundnut publication and information division, Indian council of agricultural research, Krishi anusandahn bhavan, pusa. New Delhi.

Shoran, J. and Tandom, J.P. 1995. Genetic divergence in winter what (Triticum aestivum L. em. Thell). Indian Journal of Genetics 55: 406-409.

Singh, R.B. and Gupta, M.P. 1968. Multivariate analysis of divergence in upland cotton. Indian Journal of Genetics 28:151-157.

Singh, R.K. and Chaudhary, B.D. 1985. Biometrical Methods in Quantitative Genetics Analysis (Rev. ed.). Kalyani Publishers, New DelhiLudhiana. 78 pp.

Singh, R., Kharb, R.P.S. and Singh, V. 2003. Genetic divergence study in durum wheat based on seed vigor parameters. Wheat Information Service 96:20-22.

Singh, S. and Gupta, P.K. 1979. Genetic divergence in pearl millet. Indian Journal of Genetics 39:210-215.

Singhal, N.S. and Upadhyay, M.K. 1977. Genetic divergence in wheat. Cereal res. Commun. 5: 275-286.

Tanner, D.G., Amanuel, G. and Zewde, K. 1991. Wheat agronomy research in Ethiopia. In: Wheat research in Ethiopia: A Historical Perspective. Hailu, G.M., Tanner, D.G. and Hulluka, M. (Eds.), pp. 95-130.

Vavilov, N.I. 1951. The origin, variation, immunity and breeding of cultivated plants. Chronica 13: $1-366$.

Walia, D.P. and Garg, D.K. 1996. Evaluation of genetic divergence in wheat (Triticum aestivum L.) germplasm. Indian Journal of Genetics 56:452-457.

Zohary, D. 1970. Centres of Diversity and centers of Origin: In: O.H. Frankel and E. Bennett (Eds.) Genetic Resources in Plants. Their Exploration and Conservation. I.B.P. Handbook 11: 33-42. 